Again, in a certain district, a large teaching hospital arranged with the Hospital Savings Association te have a special building erected as an ophthalmic clinic under the N.O.B. where all their patients were examined by the staff of the eye department of the same hospital. Not one of the local practitioners was included. "All the king's horses and all the king's men" as - represented by the B.M.A. were unable to help. It was a private arrangement betweef the H.S.A. and the teaching hospital and the N.O.B. May I submit therefore that the policy of the N.O.B. ought to be strictly supervised by the Medical members only and that all "private arrangements" of official and unofficial kinds ought to be strictly eliminated as a canker in the heart of a supposedly learned and dignified profession.

I remain, Yours etc.,

LoNDON, June 6, 1944.

\title{
N. Pines.
}

\section{OBITUARY}

\section{JOHN ARCHIBALD VALENTINE}

Mr. Harrison Butler writes :-

Within ten days death has removed from our midst two prominent Irishmen, first J. A. Valentine, and then R. J. Coulter. It was my good fortune to know them both and it is my sorrow to mourn their loss. I first met Valentine at the Oxford Congress. He was an almost constant attendant, and did much to enliven the proceedings by his native Irish wit, and buoyant good fellowship. $\mathrm{He}$ had a fund of amusing stories, but they never transgressed against the dictates of decency. At the meetings his remarks, always. characterised by his joie de vivre and merry humour, were eminently practical and useful. Valentine enjoyed the blessing, to-day"rare, of a cultured education. He had, at Trinity College, Dublin, a brilliant career in both classics and medicine. He held the degrees of B.A., M.D., B.M., B.Ch. and B.A.O. Dublin, in 1902. He was L.M. of the Rotunda Hospital, Dublin, and D.T.M. and H., Cambridge University. He was awarded the Haughton Clinical Medal in Medicine. He studied for some time in Vienna.

After qualification, Valentine, generally known to his intimates as "Archie," worked in the tea plantations of India where he gained a sound knowledge of tropical medicine, of ophthalmic work, and what was even more valuable, of men. In the last great war he served in Salonica, where his knowledge of malaria was of great value to the army.

After the peace he returned to Southsea and devoted himself solely to ophthalmology. He was surgeon to the Portsmouth and 
Southern Counties Eye and Ear Hospital and ophthalmic surgeon to the Royal West Sussex Hospital, Chichester. He began his ophthalmic life as clinical assistant to the Royal Victoria Eye and Ear Hospital, Dublin. A few years ago he took into partnership Nigel Cridland, son of the well known Secretary and Master of the Oxford Congress. At the outbreak of war Cridland joined the forces and Valentine was obliged to resume extended duties and was in full activity till a few hours before his death, which took place on March 27. He took a great interest in the Portsmouth and Southsea Rotary Club, and was a keen Freemason.

Valentine was an enthusiastic yachtsman, and was ViceCommodore of the Portsmouth Sailing Club, and Rear-Commodore of the Royal Portsmouth Corinthian Yacht Club. Nowhere was he happier than in his small yacht surrounded by one or more members of his family and their friends. It seems but yesterday when I saw his small yacht sailing into Yarmouth, Isle-of-Wight, and had a chat with him on that most fascinating of all sports, small boat sailing. During his whole professional career he was ably supported by his wife, herself the daughter of a well known Dublin medical teacher, Professor Walter Smith. She was a frequent visitor at the Oxford Congress. He is survived by two daughters, one an officer in the W.A.A.F., and the other in the V.A.D. His only son died at Sherborne School. Our sympathy goes out to them all. They have lost a devoted father, and many of us a dear friend. Valentine was deeply moved by the recent developments in the outlook of the medical profession, and especially in the future of ophthalmic surgery. He did not see eye to eye with the British Medical Association, holding quite rightly as many of us think, that no patient in these days should be seen for the reduced fees recommended by the Group Committee. He maintained his views actively and with his characteristic courage.'

\section{GEORGE LINDSAY JOHNSON}

THE death of G. Lindsay Johnson at Durban, Natal, on August 1, 1943, was noted in our December number.

Through the kindness of the Council of the Royal College of Surgeons and of Mr. Le Fanu, Librarian, we are now able to give some details of his career.

Johnson was born at Manchester in 1853. Much of his education was taken in Germany, and he was in Strasbourg when the Prussians seized it in 1870. After a year on a ranch in Australia, where he had relatives, he studied at Owen's College, Manchester, and at Gottingen, Caius College, Cambridge, and St. Bartholomew's Hospital. He took the M.D.Cantab. in 1890 and the F.R.C.S. in 1884 .

His ophthalmic career started when he acted as Registrar at the Royal Westminster Ophthalmic Hospital, and later he worked at the 




JOHN ARCHIBALD VALENTINE

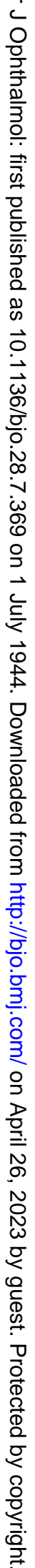

